\title{
The Spiritual Concept of Human Birth
}

\section{Satyapriya Maharana, Bapat Rashmi Atul* and Hongasandra Ramarao Nagendra}

SVYASA Open Digital Learning - DDE/ODL, SVYASA Deemed to be University, India

*Corresponding Author: Bapat Rashmi Atul, SVYASA Open Digital Learning - DDE/

ODL, SVYASA Deemed to be University, India.
Received: May 05, 2021

Published: May 19, 2021

(C) All rights are reserved by Bapat Rashmi

Atul., et al.

\section{Abstract}

A comprehensive literature survey is made on the subject of human birth according to yoga text and spiritual texts. We have reviewed the ancient text and scriptures for the concept of human birth. The soul returns to the mundane life on the exhaustion of the meritorious deeds with residual karma gains a new body suited to it from a womb. As said in Shrimad bhagawatam under the supervision of the Supreme Lord and according to the result of his work, the living entity, the soul, is made to enter into the womb of a woman through the particle of male semen to assume a particular type of body कर्मणा दैव नेत्रेण जन्तुदेह पपत्तये karmanā daiva netrena jantudeha papattaye SB3.33.1. After being connected with a progenitor the soul with the residual karma enters a womb and gains a body suited to the experience of its karma. The birth is high or low, according to the nature of residual karma. An explanation of Karma theory for human birth is also given with the yoga dimension. After the study of the relevant literatures, it is formed that it is the law of karma which decides an individual's birth.

Keywords: Human Birth; Chromosomes; Karma

\section{Introduction}

The birth of a child is generally considered a blessing and a source of great joy. It arouses extremely tender feelings in all those who are close to the child and is accompanied by various rituals and ceremonies in different countries. It is a perfectly natural instinct to have a child. The love between the mother and father helps create a happy family atmosphere and the child forges a closer link between the parents. The mother and father ensure that their sons and daughters receive proper care and they strive hard to create the best conditions for their children's physical, mental, emotional, intellectual and spiritual development. In the present age all these have undergone tremendous changes. The materialistic way of life has diluted the faith in spirituality. Today, the medical science has advanced in astonishing ways. Our knowledge of science enables us to solve the most complicated and puzzling problems. We have understood many intricate details about nature ranging from as- tronomical phenomena to atomic motion. Yet, with all available scientific knowledge, many happenings in the world are still beyond our understanding.

Birth is one such fascinating phenomenon which has many facets and unanswered questions.

Science and technology has understood most of the aspects of 'how' of the physical processes involved in the formation of an egg, its development and maintenance that culminates in the birth of a baby. Accordingly, the basic cells that are needed for fertilization are just one ovum and one sperm. The single cell that results from this union quickly becomes an embryo. It multiplies by successive divisions, and the progeny transforms into different kinds of cells, like brain cells, bone cells, muscle cells, nerve cells, gland cells, etc, whose systematic arrangement forms a beautiful functional enti- 
ty, the human embryo. As every cell has a detailed template of all parts of a body embedded within its nucleus as 46 bundles (chromosomes) of information, it is up to the cell to unfold one of those bundles, adopt one of the genes in it, and follow it up, to become a component of one particular part of the body.

The new techniques of assisted reproduction have helped enormously the women who have not been able to conceive in the natural course. The ovum and sperm are fertilized outside the female body (In Vitro) and later implanted into the uterus for further development of the embryo. Techniques like IVF (In Vitro Fertilization), ICSI (Intra Cyto Plasmic Insemination), SIFT (Sperm Intrafallopian Transfer), GIFT (Gamete IntraFallopian Transfer) etc, are giving remarkable results to the infertile couple. The latest in the news is cloning that has produced the first cloned human. This could mark the start of a new era in human reproduction -first time in the history of mankind, a child has not been the product of a genetic mix of ovum and sperm, but it is the identical copy of one parent".

As science unfolds newer understandings about reproduction, we wonder whether there are other ways of producing life. This brings us to the concept of supernatural human powers in creating life. Vedas, Upanishads, Bhagavad-Gita, Epics like Ramayana and Mahabharata, and also Mahapuranas are full of these instances of birth i.e. birth without the mix of female and male, in more miraculous than the scientists could conceive. A controversial cult exists that says mankind was created by extra-terrestrials. Kunti in Mahabharata gave birth to Karna by chanting the sun mantra given to her by sage Durvasa. It is said that Sita was born from the Earth and Janaka, the king, found her while the land was being ploughed. Ramayana mentions that king Dasharatha received paaysam given by Vishwamitra during putrakamesti yagna to be given to his wives to beget children, Rama, Laxmana, Bharatha and Shatrughan were born out of this. Similarly Hanuman is regarded as the son of the wind God. In the Sankhya and Yoga systems of philosophy there is vast literature of instances of human reproduction by using supernatural powers. Yoga Vasishta, Gheranda Samhita, Hatha Yoga, Yoga Choodamani are also full of these occult human powers. Maharshi Patanjali has vividly described Asta Siddhis that can be acquired by practice of yoga Samadhi. Looking at these literatures and patanjali's explanations of Nirodha, Samadhi and Ekagrata parinama, it appears that yoga/spiritual masters had the power not only to bring about changes in the structure of the body by changing the programming within the genes, but also had the potential to create a whole new human being bestowed with desired qualities. It appears that, by acquiring mastery over energy and matter, the ordinary laws of nature could be circumvented. By these occult powers, one could do anything and everything. In those days of such great masters (yogis), mental powers appeared to be much stronger than the material powers. It I stated that life could be created by a mere hand gesture (mudra), by a mere mantra or by a mere prasada through divine grace. Other questions not addressed by the science Embryology or obstetrics are: 'why a human birth?' and 'what is the final purpose of human birth?' etc. These questions are addressed as important topics in these spiritual/yoga texts with great logical clarity as they are directly relevant to one's life. Rebirth caused by strong imprints produced by one's right or wrong deeds during life (Kama theory) is the greatest contribution of this knowledge base which must have evolved through several years of search. The yoga scriptures are convinced that birth takes place because of one's past Karma. Many other religious scriptures like Buddhism, Jainism, Islam and Catholic theology also believe in these phenomena in nature viz. the law of karma, rebirth and supernatural yogic powers. The parentage, the fetal life, the span of life and the quantity of life are all decided by the law of Karma.

"Man is the maker of his own destiny"

\section{Swami Vivekananda.}

\section{Literary Review}

Work done earlier in the field.

\section{Summary}

These studies have highlighted the pregnancy its complication, concept of high risk pregnancy as per Ayurveda literature, concept of antenatal care from the point of view Ayurveda and conventional medicine, Apart from these concept of conception from the text of yoga and spiritual lore, effect of yoga on high-risk pregnancy and different effective management to eradicate the complication of pregnancy were presented. From the point of view of Ayurveda and ancient yogic text and spiritual lore. In one of the study physiological changes of pregnant women were also illustrated. 


\begin{tabular}{|c|c|c|}
\hline \multicolumn{3}{|c|}{ MSc dissertation work } \\
\hline $\begin{array}{l}\text { Chetana } \\
\text { Deshpande } \\
2008\end{array}$ & $\begin{array}{l}\text { Pregnancy its complication and } \\
\text { managements. }\end{array}$ & $\begin{array}{l}\text { This study described the introduction and month wise physiological } \\
\text { changed during pregnancy. } \\
\text { About categories, complication and causes of high risk pregnancy and } \\
\text { management of high risk pregnancy as per modern text. }\end{array}$ \\
\hline $\begin{array}{l}\text { Jayashree R. } \\
\text { Hegde } \\
2011\end{array}$ & $\begin{array}{l}\text { A comparative study on the con- } \\
\text { cept of antenatal care (Garbhini } \\
\text { Paricharya) from the point of } \\
\text { view of Ayurveda and conven- } \\
\text { tional medicine. }\end{array}$ & $\begin{array}{l}\text { This study explored the concept of antenatal care, the traditional } \\
\text { methods of caring pregnant women, and comparing to the under- } \\
\text { standing of pregnancy and their caring in modern times. Despite of the } \\
\text { modern materials and methods to facilitate comfortable pregnancy } \\
\text { period, many of the features of antenatal caring practices during many } \\
\text { centuries ago are still relevant and used in the conventional method of } \\
\text { antenatal care. }\end{array}$ \\
\hline $\begin{array}{l}\text { Leena Kumari M. } \\
\qquad 2013\end{array}$ & $\begin{array}{l}\text { The physiological changes of } \\
\text { pregnant women according to } \\
\text { Scriptures. }\end{array}$ & $\begin{array}{l}\text { This study explained the principles laid down by Ayurveda texts } \\
\text { extremely relevant and useful in taking care of pregnant women, who } \\
\text { undergo many physiological changes. The study also highlighted the } \\
\text { changes, usefulness and detail methods of usage of herbal drugs to } \\
\text { prevent the forth coming problems in pregnancy. }\end{array}$ \\
\hline $\begin{array}{l}\text { Satyapriya } \\
\text { Maharana, } \\
2003\end{array}$ & $\begin{array}{l}\text { Concept of conception in the text } \\
\text { of yoga and spiritual lore. }\end{array}$ & $\begin{array}{l}\text { This is a comprehensive literature survey of the concept of concep- } \\
\text { tion according to modern medicine, spiritual texts viz., Vedic age, } \\
\text { Upanishats, Bhagavat Gita, Epics, Puranas and also according to other } \\
\text { religions. Instances of reproduction of human beings that could hap- } \\
\text { pen by Siddhis and go beyond the common laws of nature i.e., without } \\
\text { the ovum and sperm coming together were quoted. }\end{array}$ \\
\hline \multicolumn{3}{|c|}{ PhD thesis work } \\
\hline $\begin{array}{l}\text { Abbas Rakhshani } \\
2013\end{array}$ & $\begin{array}{l}\text { Effect of Yoga in High risk preg- } \\
\text { nancy }\end{array}$ & $\begin{array}{l}\text { This vedic search coverd three sections: the first section coverd the de- } \\
\text { scription of embryology found in bhagavad purana, the second section } \\
\text { describes the pregnancy related traditional rituals called Samskras } \\
\text { that were practiced in ancient Indian society as described in different } \\
\text { vedic texts, third section is the overview on the conceptual basis for } \\
\text { the integrated yoga therapy for the high risk pregnancy as portrayed in } \\
\text { the Vedas. }\end{array}$ \\
\hline
\end{tabular}

\section{Table A}




\section{Need for the Study}

Since no literature has been found to explore the context of human birth. It was a high time for the yogic researcher to know about birth mentioned in ancient and spiritual text.

\section{Aim and Objectives of the Study Aim}

The aim of the study is to review the spiritual concept of human birth as described in Vedic literature and various scriptural texts.

\section{Objectives}

- To understand the concept of birth as mentioned in Vedic literatures.

- To compile the ancient view on the concept of birth from scriptural texts.

\section{Materials and Methods}

The literary research is based on the information collected from:

Classical yoga text:

- Yoga Vasistha, ii. Hatharathnavali, iii. Siva samhita, IV. Patanjali Yogasutras Vedic literature: i. Vedic age, ii. Upanisad, iii. Bhagvat Gita, IV. Epics, v. Puranas

The versus and relevant information from the above mentioned sources were systematically compiled, analyzed, and discussed in depth understanding of the concept of Birth. Available commentaries were explored, screened and reviewed from different ancient classical texts. The relevant references are cited in the body of the text as well as in the reference section.

\section{Inclusion criteria}

The inclusion criteria were:

- $\quad$ Focused on verses which specifically define the birth concept, even though the research result were large and texts were varied.

- Verses related to concept of Birth in relation to the law of Karma - Associated themes which related to the concept of soul and rebirth.

- $\quad$ Reincarnation in relation to physical and subtle bodies.
Exclusion criteria

The exclusion criteria were

- Verses with mere concept of birth without details were excluded.

- Inclusion of all shlokas from one text was not attended. i.e. slokas from varied texts were only considered.

- Though the search may give rich sources of information, we restricted to specific texts.

Concept of human birth in the texts of yoga

Yoga väçiñöha : yaeg vaizó

ik<tu ye äü[ae @NyTv< buXyNte saiTvkae_dva>,

kintu ye brahmaëo enyatvaà budhyante sätvikobhdaväù |

Abaeäü[ae mn> ziTkr_yuidta pur> iSwtakazziKmvlMBy tÇSwpvntamupaitnI xns<kLpTv< gCDit, .19 .

brahmaëo manaù çatkirabhyuditä puraù sthitäkäçaçakmiavalambya tatrasthapavanatämupätiné dhanasaìkalpatvaà gacchati | 19 .

tt> pur> àaÝÉuttNmaÇpcktaÉeTyaNt> kr[ta< nITva saTvsuúma àk«itÉuiTv ggnpvntejaeéptas<kLpat! àaleyéptamupeTy zLyae;aix< ivzNtI àai $[$ na $<$ gÉ $<$ ta $<$ c meCDit,

jayte tSmaNtt> pué; $<\mathrm{s}<$ p*te. 20.

tataù puraù präptabhutatanmätrapacakatäbhetyäntaù karaëatäà nétvä sätvasukñmä

prakåtibhutvia gaganapavanatejorupatäsaìkalpät präleyarupatämupetya salyoñädhiaà viçanté präëinäà gabhantäà camecchati |

jäyate tasmäntataù puruñaà sampadyate || 20 ||

ten pué;en jatmaÇe[Ev baLyaLyaàÉ\&it,

iv*aథh[< ktRVy< gurvae @nugNtVya >. 21.

tena puruñena jätamätreëaiva bälyälyäprabhåti |

vidyägrahaëaà kartavyaà guravoa enugantavyä ù || 21 ||

tt> ${ }^{3}$ maTpu $<$ rtvev cmTk«itjaRyte. 22.

tataù kramätpuaàrataveva camatkåtirjäyate || 22 ||

SvCDdza icÄv\&te> pué;Sy heyae;adeyivcar \%Tp*te. 23.

svacchadaçä cittavåteù puruñasya heyoñädeyavicära utpadyate \| $23 \|$ 
taÔiMvvekvit s<kiltaiÉmane pu<is iSwte ivmlsTvmya'œxyjatE.

sÝaiTmkavtrit ${ }^{3} \mathrm{mz}>$ izvay cet> àkaznkrI nnu yaegÉuiÉ>. 24.

tädramvivekavati saìkalitäbhimäne puàsi sthite vimalasatvamayäìdhayajätai ||

saptätmikävatarati kramaçaù çiväya cetaù prakäçanakaré nanu yogabhubhiù || 24 ||

This chapter mentions the process of production of body from the mind -The mental power of Brahma emerging from him, rests on the wide expanse of vacuum/space (akasha), which is spread before it. Being joined with the essence of the individual soul (sukshma sarira) it becomes solidified in the shape of desire. Then finding the miniature of matter spread out before it, it becomes the quintessence of the quintuple elements (prthvi, ap, tejo, vayu tatvas) ; this goes on to assume their outward senses ( touch, taste, smell and ........) ; it then becomes a suitable elementary body composed of the finest particles of the five elements. It enters into the grains and vegetables which re-inter the bowel of human being in the form of food. The essence of the food in the form of semen gives birth to the human being. The male child is taken in his boyhood to his tutor for acquisition of knowledge. Man attains, by degrees, the supernatural powers of his own good deeds, as also the enlightenment of his mind by means of his knowledge of the seven essential stages of yoga meditation (saptabhumika) (Ref [2], C.H.-116, Sloka No- 19, 20, 21, 22, 23, 24, P.G-579).

\section{Haöha ratnävalé : hQ rEavlI}

$\backslash$ tukale ywa $\mathrm{zu}\urcorner<$ indE; $<$ yaeins $<$ gt $<$ twa tNmaétenEv ôIretenEktaimyt!. 94.

åtukäle yathä çuklaà nidaiñaà yonisaìgataà tathä tanmärutenaiva stréretenaikatämiyat || 94 ||

Aayu $>$ kmR c ivÄ < c iv*a < cEv ctuòy< Aaxankale iloit gÉRSySyEv deihn>. 95 .

äyuù karma ca vittaà ca vidyäà caiva catuñöayaà ädhänakäle

likhati garbhasyasyaiva dehinaù || 95 ||

yav*avÖy< dehae iØyte gÉRzaiyn> tavÄavdiÉVyi'> il<gSyaSy àjayte. 96.

yävadyävadvayaà deho dhriyate garbhaçäyinaù

tävattävadabhivyaktiù lì̀gasyäsya prajäyate || 96 ||
Aayu:y< vxRte inTy< yid ibNd > iSwrae Évet! \%TpiÄ iSwit $s<$ hare ibNÊrekae ih kar[m!. 97.

äyuñyaà vardhate nityaà yadi bindaù sthiro bhavet utpatti sthiti saàhäre bindureko hi käraëam || 97 ||

Hatha ratnavali: In this text, there is the mention of reproductive organs of the female; the bindu (the vitality of the man) is to be saved by the practice of the vajroli kriya. At the time favorable for conception, pure semen enters the yoni of the woman, the ovum unites with the sperm by the healthy functioning of the vata aspect of the tridoshas (the movement aspect of subtle energies, the wind element). The span of life, wealth, education and profession are all fixed at the time of the conception itself when the union takes place in the womb and are predictable by the science of astrology (Ref [3], C.H.-II, Sloka- 94, 95, 96, 97, P.N-52, 53).

\section{Çiva Saàhitä izv s<ihta}

iNdivxNtu )l< \}ey< SvgeR nrk @v c SvgeR nanaivwíEv nrkaeip twa Évet!. 24.

ndividhantu phalaà jïeyaà svarge naraka eva ca svarge nänävithaçcaiva narakopi tathä bhavet || 24 ||

papÉaegvsane tu punjRNm ÉveTolu pu\{yÉaegvsne tu naNywa Évit Øuvm!.25.

päpabhogavasäne tu punarjanma bhavetkhalu

puëyabhogavasane tu nänyathä bhavati dhruvam || 25 ||

ipturÚmyaTkaez³/4ayte puvRkmR[a $>$ tCx $<$ raer $<$ ivÊ $\hat{E}>0<$ SvàagÉaegay suNdrm!. 28.

piturannamayätkoçajjäyate purvakarmaëäù

tacdhaàroraàvidu duùkhaà svaprägabhogäya sundaram || 28||

\#hamuÇ JlNde;I s)l< kmR s<Tyjet! inTynEimiÄk< s<\} Tyka yaege àvtRte. 31.

ihämutra phalandeñé saphalaà karma santyajet

nityanaimittikaà saïjïa tyakä yoge pravartate || 31 ||

\section{Shiva samhita}

This text also talks about the law of Karma. The fruits of action are twofoldheaven or hell. The good actions are verily the heaven, and sinful deeds take the soul to the hell; the creation is the natural outcome of Karmas and nothing else. When the suffering (hell) 
of the evil actions and enjoyment of good actions (heaven) are exhausted, the jiva takes rebirth. From the Annamaya kosa (the physical vehicle) of the father, and in accordance with its past Karmas, the human soul is re-incarnated; therefore, the wise consider this beautiful body as a punishment, for the suffering/enjoying of the effects of past Karma. Those who are desirous of enjoying the fruits of their actions in this world should renounce all actions which are done with an eye to their fruits. After having discarded the attachment for the daily and the Naimittika acts, one should employ themselves in the practice of Yoga (Ref [4], C.H.-1, Sloka no- 24, 25, 28, 31, P.N- 4, 5).

Pataïjali's Yoga Sütras ptÃil yaeg sUÇ

ᄀezmUl> kmaRzyae †òa†òjNmvednly>

kleçamülaù karmäçayo dåñöädåñöajanmavedanéyaù

zit mule liÖpakae jaTyayuÉaEga> we 'adpijlap)la>

pu\{yepu\{yhetuTvat!

Karma theory according to patanajli: The reservoir of Karmas which are rooted in Klesas brings all kinds of experiences in the present and future lives. As long as the root is there, it must ripen and result in lives of different classes, different lengths and experiences. They have joy or sorrow as their fruit according to their cause i.e. virtues or vices (Ref [5], Ch.-II, Slokas-12, 13, 14, Pg-157160).

\section{Concept of Huiman birth in the spiritual text}

The birth of an individual is the rebirth of a person who died somewhere, sometime previously. Death is not end of an individual nor is birth the beginning. According to the impressions of karma existing the mind of a dying man, a fine vesture for the subtle and the causal body is formed at the time of his departure from the gross body. This fine garb carries the potencies of the gross body he assumes. He may go to a higher or a lower region impelled by his Karma. When this karma is exhausted the residual Karma will lead him eventually to this human plane, where he has a chance for liberation. The impressions of karma will lead him to the parents from whom he can secure the materials for his gross body. The fine physical vesture that he wears has the potency to acquire the necessary, material elements, being associated with the food, he enter into the body of the male parents suitable for his purpose. There he gets into the requisite sperm, which turns in to a potent seed for his development as an individual. This is the seed that, being united with the requisite ovum in the female parent turns into the zygote and becomes ready for germination. These are the two specialized male and female reproductive cells that are responsible for the birth of the offspring (Figure 1) (Ref [7], Part-II, C.H.-VIII, P.N. - 211,212).

\section{Vedic age}

The Vedas speak of things not comprehended by the human mind. If we perform the rites imposed on us by them, the fruits thereof will naturally follow. Sound has always existed. It has indeed no beginning and no end, and the Vedas are this sound. If we do evil, consequence will be evil; if we do well the result will be correspondingly good. These Vedic rituals create wellbeing in the world, lead to a disciplined and harmonious social life and bring inner purity to the performer.

\section{Karma kanda}

According to the Karma Kánda, it is the Vedic rites performed by us that decide the fruits to be earned by us; it is our karma that brings its rewards or retribution. There are three types of karma, which mentioned in Vedas, Nitya, Naimitta and Kamya Karma. For example- Putra kámesti Yájna - It means sacrifice to get a son.

Birth- Our birth in this world is according to past karma and we have to perform the rites that are proper to it. If we do not, we will suffer. The customs and rites must be performed properly. By the virtue of his birth, each man must perform the duties allotted to him. Through this he can earn good karma for his next life (Ref [11], Part-16, Ch-9, Pg-524).

\section{Upanisad}

The soul returns to the mundane life on the exhaustion of the meritorious deeds (that leads to the Svarga loka) with residual karma by the same route by which it went to (Svarga loka). The soul gains a new body suited to it from a womb. After being connected with a progenitor the soul with the residual karma enters a womb and gains a body suited to the experience of its karma.

The birth is high or low, according to the nature of residual karma (Ref [7], Part-two, Ch-7, (59), Pg-190). 


\section{Garbha upaniñat}

The Garbha Upaniñad defines how the child's body gradually develops inside the womb.

From the union of the semen and the blood develops the embryo; "in the heart are the parting" as they say. Particularly in the heart is a fire, by the fire is bile, and by the bile is wind, and where the wind is, there goes forth the heart (of the child) in consequence of a creative process. The first day after conception the embryo looks like nodules, seven days after like a bubble, fifteen days later like a mass, which hardens after one month. The head appears after two lunar months, and part of the feet by the end of the third month. During the fourth month, the ankle, the stomach, and hips are formed while during the fifth, the spinal column is formed, followed in the sixth monthly the nose eyes and ears. In the course of the seventh month, the embryo is equipped with a soul, jiva and the child is completely formed by the eighth month. Again according to the Garbha Upaniñad, as of the ninth lunar month, the soul is able to perceive Prakøti, Mahat, Ahañkára, 5 Tanmatrás, Manas, 10 Indriyas, 5 Mahabhütas a total 25-tattvas come to the jèva.

- पन्चात्मकः सम्रथः

पन्चात्मकतेजसेद्धरसश्च सम्यग्ज्ञानत् ध्यानात् अक्षरमोडकारं चन्तियता तदेतदेकाक्षरं ज्ञात्वाsष्टौ प्रकृतयः षोडश वकिारः शररि तस्यैवे देहनिम्

अथ मात्राऽशतिपीतनाडी सुत्रगतेनप्राण आप्यायते !अथ नवमे मासा सर्व लक्षण संपुर्णो भवता पुर्वजातः स्मिरता कृता कृतं च कर्म वभितश शुभशुभं च कर्म वन्दिन्ता !। !!

नानायोनसिहस्त्राणा द्रिष्ट्वा चैव ततो मया!

आहारा वविधिभुक्ताः पतिश्च्च वविधिः स्तनाः!

जातस्यैव मृतस्यैव जन्म चैव पुनः पुनः अहो दुःखो दधौ मग्नःन पश्यमा प्रतक्रियिम् यन्मयापरजिन्स्यार्थे कृतं कर्म शुभशुभम् एकाकी तेन दहयमागतास्ते फलभोगनिः!!

This monolog of this Upanishads is the uniqueness. The fetus as the soul now realizes his all good and bad deeds. Now the soul is able to remember his previous incarnations and action and why depending on his karma, she/he must reincarnate. At the moments of birth, the soul is no longer able to remember its past, but in accordance with the law of karma, which is just, the individual will be drawns from his earliest childhood to situations and condition of life, which he will have deserved as a result of his thoughts and action in formers lives and which will enable him to pass through the experience, necessary to his evolution.

- यदयिन्यां प्रमुज्चामसिांख्यं योगं समाश्रये अशुभ क्षय कर्तारं फ़लमुक्तप्रिदयकम्

- यदयिन्यां प्रमुज्चामतिं प्रपद्दे महश्वरम् अशुभ क्षय कर्तारं फ़लमुक्तप्रिदयकम्

- $\quad$ The soul pray to lord Mahesh war, lord Narayan and lord brahma to rescue him and he will learn the Samkhya yoga and contemplates on the Brahman.

- This is called as pipalad moksha Shastra as by contemplating on garbha monologues the aspirtant achives onsess with self and there by the process of cycles of birth and death gets cut off by his/her own karma. (The theory of karma siddhanta by Avinash SGP; Bapat RA (2021). The Study of Karma Sidhhanta and Astrology on the Human Longevity Based On Karma. Global J Appl Sci Technol 2(1): 110)

- $\quad$ (Ref [12], (E. The Upanisad of the Atharva Veda553-888), Part-II, 17-G.U., P.N.-639-644).

\section{Båhadäraëyaka Upaniñat}

Aw ye y\}en danen tpsa laekaÃyiNt te xUmmiÉsMÉviNt, xUmaÔaiÇm! raÇerp]Iyma[p]m! , Ap]Iyma[p]a*aN;\{masaNdi][aidTy @it, mase_y> ipt\&laekm, ipt\&laekaÂNÔm te cNÔ< àaPyaÚ< ÉviNt ta $<$ StÇ deva ywa saem< rajanmaPyaySvap]IySveit @vmena $<$ StÇ É]yiNt te;a< yda tTpyRvETywemmevakaZmiÉin:p*Nte AakazaÖayum vayaev\&Riòm v\&òe> p\&iwvIm! te p\&iwvI- àaPyaÚ< ÉviNt te pun> pué;ađaE $\div$ yNte ttae yae;ađaE jayNte laekaNàTyuTwaiyn> t@vmevanupirvtRNte Aw y @taE pNwanaE n ivÊSte kIqa> pt¹/4a yidd $<$ dNdzUkm!. 16. \#it iÖtIy< äaü $\{$ m!.

Aatha ye yajïena dänena tapasä lokäïjayanti te dhümamabhisambhavanti dhümädrätrima rätrerapakñéyamäëapakñama apakñéyamäëapakñädyänñaëmäsändakñiëäditya eti mäsebhyaù pitålokama pitålokäïcandrama te candraà präpyännaà bhavanti täàstatra devä yathä somaà räjänamäpyäyasväpakñéyasveti evamenäàstatra bhakñayanti teñäà yadä tatparyavaityathemameväkäçmabhiniñpadyante äkäçädväyuma väyorvåñöima våñöeù påthivém te påthivéà präpyännaà bhavanti te punaù 
puruñägrau huyante tato yoñägrau jäyante lokänpratyutthäyinaù ta evamevänuparivartante atha ya etau panthänau na viduste kéöäù pataìgä yadidaà dandaçükam || 16 || iti dvitéyaà brähmaëm II

While those who win (various) world through sacrifices, gift and penance, reach (the deity of) smoke, from him (the deity of) the night, from him (the deity of) the fortnight in which the moon wane. From him (the deities of) the six months during which the sun travels southward, from them (the deity of) the world of the manes, and from him the moon. Reaching the moon they become food. There the gods eat (utilize) those (who have arrived) there, just as (priests) during the bright Soma juice (saying, as it were) 'Increase, Decreases', And their past work is exhausted, they reach this very ether, from the ether the air, from the air rain, and from rain the earth. Reaching the earth they become food. (Then) they are again offered in the fire of a male, then in the fire of women; (then) they are born (and perform rites) for rising to (other) worlds. Thus verily they rotate. Thus, whoever, who do not know these two way become insect month and all these oft- biting creatures.

\section{Chändogya Upaniñat}

yae;a vav gaEtmaiđStSya \%pSw @v sim*ÊpmÙyte s xUmae yaeinricRyRdNt $>$ kraeit te $=1 / 4$ ara AiÉnNda ivS^)...il11/4a> 1 . tiSmÚetiSmÚgaE deva retae jupit tSya Aa $\div$ tegRÉR> sMÉvit. 2.

tiSmNyavTsMpatmui; TvawEtmevaXvan $<$ puninRvtRNte ywetmakazmakazaÖayu< vayuÉURTva xUmae Évit xUmae ÉUTvaæ< Évit. 5.

Aæ< ÉUTva mexae Évit mexae ÉUTva àv;Rit $t$ \#h ìlihyva Aae;ixvnSptyiStlma;a \#it jayNte=tae vE olu ÊinR:àptr< yae yae üÚmiÄ yae ret> isÂit tÑfy @v Évit.6.

t* \#h rm[Iycr[a A_yazae h yÄe rm[Iya< yaeinmap*erNäaü[yaein va ]iÇyyaein va vEZyyaein vaw y \#h kpUycr[a A_yazae h yÄe kpUya< yaeinmap*erÁñyaein< va sUkryaein< va c\{falyaein< va. 7 .

yoñä väva gautamägnistasyä upastha eva samidyadupamantrayate sa dhümo yonirarciryadantaùkaroti te’̀̀gärä abhinandä visphulì̀gäù || 1 || tasminnetasminnagau devä reto juhvati tasyä ähutergarbhaù sambhavati || 2|| tasminyävatsampätamuñitväthaitamevädhvänaà punarnivartante yathetamäkäçamäkäçädväyuà väyurbhütvä dhümo bhavati dhümo bhütväbhraà bhavati || 5|| abhraà bhütvä medho bhavati medho bhütvä pravarñati ta iha vréhiyavä oñadhivanaspatayastilamäñä iti jäyante'to vai khalu durniñprapataraà yo yo hmannamatti yo retaù siïcati tadbhüya eva bhavati $\|6\|$ tadya iha ramaëéyacaraëä abhyäço ha yatte ramaëéyäà yonimäpadyeranbrähmaëayoni vä kñatriyayoni vä vaiçyayoni vätha ya iha kapüyacaraëä abhyäço ha yatte kapüyäà yonimäpadyeraïçvayonià vä sükarayonià vä caëòälayonià vä. || 7 ||

Women indeed is the fire, 0 Gautama. Into this fire the deities offer the oblation of the seed. Out of the oblation the foetus arises. || 1 and 2 ||

Residing in that (region of the moon) till they have exhausted (the results of action), they then return, again, the same way as they came (by the path is being mentioned), they come to Akas'a, and from Akas'a to air. Having become air, they become smoke. Having become smoke they become the white cloud. || 5 ||

Having become the white cloud, they become the (rain bearing) cloud. Having become the cloud fall as rain. Then they are born in this world as rice and barley, herbs and trees, sesamum plants and beans, but the release from these is more difficult, for whoever eats the food and sows the seed, they become like him only. || 6 ||

Among them, those who have good residual result of action here (earned in this world and lift residue after the enjoyment in the region of the moon), quickly reach a good womb, the womb of Brahmana, or of a Ksatriya or of a Vaisya. But those who have bad residual results of action quickly reach an evil womb, the womb of a dog or of a hog or of a Candala. ||7\|

\section{Kaöha Upaniñat}

yaeinmNye àp*Nte zrIrTvay deihn $>$, Swa[umNye=nus<yiNt ywakmR ywaïutm!.7.

yonimanye prapadyante çarératväya dehinaù.

sthäëumanye'nusaàyanti yathäkarma yathäçrutam. .7.

Some soul enters the womb for acquiring bodies and other follow the motionless, in accordance with their work and in conformity With their knowledge. 


\section{Aitareya Upaniñat}

' pué;e h va Aymaidtae gÉaeR Évit ydetÔet>, tdetTsveR_

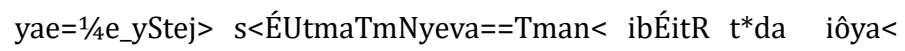
isÂTywEn $3 / 4$ nyit tdSy àwm< jNm. 1 .

om puruñe ha vä ayamädito garbho bhavati yadetadretaù. tadetatsarvebhyo'ìgebhyastejaù sambhütamätmanyevä"tmänaà bibharti tadyadä striyäà siïcatyathainajjanayati tadasya prathamaà janma. 1.

tiTöya AaTmÉUy $<$ gCDit ywa Svm $1 \frac{1}{4}<$ twa, tSmadena $<$ n ihniSt, sa=SyEtmaTmanmÇ gt< Éavyit.2.

tatsriyä ätmabhüyaà gacchati yathä svamaìgaà tathä. tasmädenäà na hinasti. sä'syaitamätmänamatra gataà bhävayati. .2

sa ÉaviyÇI ÉaviytVya Évit, t< ôI gÉi ibÉitR, sae= $\$$ @v k...mar< jNmnae $=\$ e=i x E ́ a v y i t$, syTk...mar $<$ jNmae $=\$ e=i x E ́ a v y T y a T m a n m e v$ tÑavyTye; $<$ laekana < sNtTya, @v< sNtta hIme laekaStdSy iÖtIy< jNm. 3.

sä bhävayitré bhävayitavyä bhavati. taà stré garbhaà bibharti. so'gra eva kumäraà janmano'gre'dhibhävayati.

sa yatkumäraà janmano'gre'dhibhävayatyätmänameva tadbhävayatyeñäà lokänäà santatyä. evaà santatä héme lokästadasya dvitéyaà janma. 3.

In man indeed is the soul first conceived? That which is the semen is extracted from all the limbs as their vigour. He holds that self of his in his own self. When he shed it into his wife, then he procreates it. That is its first birth. That becomes non-different from the wife, just as much as her own limb is. Therefore (the foetus) does not hurt her. She nourishes this self of his that has entered here (in her womb). She, the nourisher, becomes fit to be nourished. The wife bears that embryo (before the birth). He (the father) protects the son at the very start, soon after his birth. That he protects the son very beginning, just after birth, thereby he protects his own self for the sake of the continuance of these worlds. For thus is the continuance of this world ensured. That is his second birth. This self of his (viz the son) is deputed (by the father) for the performance of virtuous deeds. Then this other got self as his (that is the father of the son), having of his duties fulfilled and having advance in age. Departs. As soon as he departs, he takes birth again. That is his third birth.

\section{Mäëòükya Upaniñat}

\#òapUt; mNymana viró< naNyCÀeyae vedyNte àmUFa>, nakSy p\&óe te suk«te=nuÉUTvem $<$ laek $<$ hIntr $<$ va ivziNt. 10.
Iñöäpürtaà manyamänä variñöhaà nänyacchreyo vedayante pramüòhäù. näkasya påñöhe te sukåte'nubhütvemaà lokaà hénataraà vä viçanti. 10.

The deluded fools, believing the rites inculcated by the Vedas and the smrtis to be the highest, to not understand the other thing (that leads to) liberation. They, having enjoyed (the fruit of action) in the abode of pleasure on the heights of the heaven, enter this world or an inferior one.

\section{BHAGAVAT GITA}

Soul:

$n$ jayte ièyte va kdaicn!

nay< ÉUTva Éivta va n ÉUy>,

Ajae inTy $>$ zañtae $=y<$ pura[ae

n hNyte hNymane zrIre. 2-20.

na jäyate mriyate vä kadäcin näyaà bhütvä bhavitä vä na bhüyaù | ajo nityaù çäçvato'yaà puräëo na hanyate hanyamäne çarére || 2-20|| (Ref [7], paer2 Viii, 4 (B.G II; 20), Page-199).

This (the self) is never born, nor does it die. It is not that not having been it again comes into being. This is unborn, eternal, changeless, and though ancient ever new. It is not killed when the body is killed.

\section{Concept of birth:}

\%ÏredaTmnaTman< naTmanmvsadyet!,

AaTmEv ýaTmnae bNxuraTmEv irpuraTmn>. 6-5..

Uddharedätmanätmänaà nätmänamavasädayet |

Ätmaiva hyätmano bandhurätmaiva ripurätmanaù || 6-5 ||

The Bhagvat Gèta speaks about the endless chain of birth and death. We have to be born again and again because of the doctrine of karma. Sri Krishna says-the law of karma rules out fatalism, accidentals and naturalism in human affairs. No super natural power determines the event of mans life. There is no scope for chance in man's human existence. It is not blind nature that motives human action. Karma is ever associated with self-determination. The soul is bound to this law of karma (Ref [7], Part-2, Ch-V, 4 (B.G VI: 5), Pg-134).

Ainòimò $<$ imï $<\mathrm{c}$ iÇivx $<\mathrm{kmR}[>] \operatorname{lm}$ !,

ÉvTyTyaigna< àeTy n tu s<Nyaisna< Kvict!. 18-12.

Aniñöamiñöaà miçraà ca trividhaà karmaëaù phalam |

Bhavatyatyäginäà pretya na tu sannyäsinäà kvacit || 18-12 || 
Sri Krishna says that, there are three types of actions called desirable, agreeable, and mixed - awaits the non- relinquishes (of fruits) after death but not the relinquished, So we find that a man who goes to heaven as a result of his meritorious deeds may perchance have some evil impression predominant in him on the exhaustion of his merits. Consequently such a person, in coming down from heaven, will have a low birth in the human plane or may even descend to the subhuman level. Usually those who return from the heaven are reborn on a high level of life. Therefore karma decides the birth of a soul. (Ref [7], Part-2, Ch-VII, 8 (B.G XVIII: 12), Pg-191).

\section{Epics}

\section{Mahabhárata}

In Mahabharata there are several incidents which show that the mother has a great responsibility in determining and influencing the direction her children will take in their lives. That influence continues throughout the infancy and childhood. But begins even before birth. The thoughts desires and the wishes of the mother have the power to impress her unborn child with personality characteristics, it will have as it grows up. This is the essence of strip culture, the science of prenatal care and, in what conditions a child is conceived and nurtured in the wombs, how he is influenced by his parent's feelings, thoughts, and actions before and after birth predetermine to a vast degree moral fibre, talents, mental capacity, ability, state of health and even longevity.

In Mahabharata, when Vichitra Vèrya died leaving behind his two wives issueless. Satyavati was very much dejected because of the successor for the kingdom. So she called her first son Vyasa and told him her problem. Vyasa said, I agree with your desire. But I have inferior complexion for which they should not be disgusted by looking at me Satyavati agreed with the condition and called Ambica and told regarding the Circumstances of getting a child for the kuru house.

Ambica agreed to Satyavati's word, it was a pitch dark night when she saw vyasa and got terribly scared and closed her eyes, throughout the night. The very next day vyasa told Satyavati, a brave, strong, powerful son would be born to Ambika but the child would be born blind, because of her closing eyes, similarly Ambalika got frightened, while saw the Rishi for which she got a handsome, gentle nature child. Once again Satyavati requested to vyasa to take one more chance for Ambica. But this time Ambica sent her maid servent, whom vyasa met in the night, she was very attentive to every wish of his, vyasa was immensely pleased with her. Next morning vyasa told Satyavati that a wise and good son would be born, that he could be the incarnation of the lord of Dharma (Ref

\section{[13], CH-10, Pg-7).}

In the case of Kunti, she got a boon from øúi Durvasa, that she can call the divine to earth through a special Mantra (power), once she utter the mantra in front of sun god, Then the son god appeared in front of her. The mere presence of the divine creates an imbalance in the womb. That made her pregnant, and then she gave birth to Karna. That is why Karna came to have all the wise qualities of his father. Similarly it happened in the case of Yudhistire, Bhima, Arjuna, Nakula and Sahadeva. Because of that Yudhisûire was the embodiment of Dharma, Bhima was the most powerful character and the Arjuna was the greatest warrior of the world. These people are having all the divine qualities from their divine fathers (Ref [14], Pg-9, 15).

In another story of Mahabharata we hear how Arjuna's wife, listening to the tales of battle told by her husband, desired to conceive a child similar to the warriors in the stories. In the end she gave birth to a hero, Virabhimanyu, who knew all the secrets of the art of war without ever having had to learn them, while in the womb, Virábhimanyu had in fact overheard his father revealing the secrets to his mother, that is why he was an invincible hero from early youth onwards. All these events show that the mother has a great responsibility in determining and influencing the direction her children during conception and after childbirth (Ref [15], Ch10, Pg-116).

\section{Ramáyana}

During this period, it was customary thinking in India that one who was considered holy and high souled, was taken to have been born by some unique process and not by means of sexual intercourse, For example Sita was said to have born of the womb of the earth and the birth of the Rama was due to his mother Kauùalya having taken the fruits given by the Rishis to Dasaratha. Hanuman is regarded as the son of the wind god. As for Shri Lakshmi and Narayana, the example is too plain to explain. Thus in India, it was the basic religious view that the holy ones, were not born of sexual intercourse (Ref [6], P-II, Ch-35, Pg-387).

\section{Maha purána}

\section{Bhagvat mahapurána}

By force of karma (destiny) as directed by providence, the soul (destined to be born as a man) enters the womb of a woman through the generative fluid of a man for the formation of the body. The human soul, which regards the body as his own. Self is much afraid (of the gestation being repeated in other such births) and with joined palms entreats and extols him by whom he was cast into 
the womb, in a tone full of agony. The human soul says", I bow to the divine. Who is having embraced, Maya in the form of this psychophysical organism? (Consisting of the gross elements, the Indriyas and mind). In this womb, appears as bound by virtuous and sinful acts. And has his reality screened by Maya. But who flashes on my afflicted heart as absolutely pure (untainted by Maya) immutable and possessed of wisdom which knows to break. Having forgotten his own self under the influence of the Lord's Maya, the embodied soul travels the path of Samsara (transmigration). The jiva knower of the present, past and future, prays to divine to get out from the several pains. Which he is getting in his mother's womb, along with blood, faces, urine and pain of gastric fire. With over flowing piety, the jiva prays to the divine counting his months. The jiva says to divine through living in the womb, a life full of numerous troubles. $\mathrm{O}$ Lord, I have no desire to get out of it and descend into the pit fall of the outside world. For the lord's (your) Maya overtakes the soul, who goes there and in the wake of Maya appear the false notion of (I) and consequent cycle of birth and death. Therefore having installed in my heart the divine who is shaking off all the destruction of mind. I can quickly free from the Samsara sagar (worldly ocean). When the ten-month jiva, who has thus resolved even while in the womb extols the lord as aforesaid. The wind that helps parturition propels him forth with his face turned downward. In order that the child may be born, pushed downwards all of a sudden by the wind. The child issues out (of the womb) with great trouble, head downwards, breathless and deprived of memory out of agony, fallen on earth in a pool of blood and urine (discharged by the mother). The new born babe tosses like a worm sprung from ordure and having lost its wisdom (acquired in the womb) and reduced to a state of self-identification with the body (which is just the reverse to wisdom), cries loudly (Ref [16], Ch-31, Pg-274, 275, 276, 277, Slokas-10, 12, 14, 15, 16, 17, 19, 20, 21, 22, 23).

\section{Markandeya purana}

The concept of birth and conception of jiva in Markandeya purána closely resembles the account given in Bhagvat purana (Ref [17], Ch-10, Pg-40).

\section{Garuda purana}

In Garuda purána the philosophy is the, But here there is a description regarding conception and composition of human body. This texts, give certain rules and regulations for good conception. The husband should approach the wife on the $16^{\text {th }}$ day of her monthly cycle for good conception. The wife should have sáttvic food, because it affects the unborn child. The surrounding place should be full of flowers and fragrance. During the intercourse the parents should have calm and quite attitude. Because, if the parents have bad thoughts, the mental attitude is going to affect the newborn child. When the sperm and ovum and the soul come together, the germination takes place. To get a Dharmic child, parent should be performing samskras related to birth. This Purana gives a description of the components of the body. the physical body is made of PAÒCHA MAHABHÜTAS, THE MIND, INTELLECT, EGO, CHITTA, ANTAÇ - KARANA, PAÒCHA- JNÁNE INDRIYAS, PAÒCHA-KARMEINDRIYA,72 LAKHS NADIES including Ida, Piògala, and Suùumna and all the past life karma also come to the body in physical human body there are 7 lakhs hair 20nails, 32 teeth, sapta dhatu and 360 bones. In subtle body 14 lokas, 7 mountains, 9 planets, 6 charkas, all the qualities which are in the universe, all are also present in the subtle body (Ref [18], Ch-15, Pg-310).

\section{Concept of rebirth and reincarnation}

The doctrine of rebirth and reincarnation is complementary to the doctrine karma. The law of karma is the chain that ties man to the wheel of birth and rebirth. This is the cause of bondage and liberation. This is based on a comprehensive and consistent view of human personality comprising its present, past and future. It accounts for the settled facts of life. It maintains the identity of an individual throughout a succession of births and deaths. One and the same individual appears in different physical garbs. But all along retains the same mind, which is separable from the body. This doctrine explains man's present existence with reference to his past and future. It birth be the beginning of life than death must be its end. Rationally we cannot accept future life without acknowledging our existence in the past. The assumption of future life is based on the recognition of the present life, as it's pre-condition. Man's soul is not actually born nor does it die, but transmigrates for the time being under the law of karma. This doctrine is a sequence of the law of karma. It has support among the world's theologians, philosophers, mystics, scientists, poets and psychologists. Swami Vivekananda-says if you are going to exist in eternity hereafter, it must be that you have existed through eternity in the past; it cannot be otherwise. Eternal existence with a beginning is absurd. What begins in the time must end in time (Ref [7], Part-2, Ch-VIII, Pg-194, 214).

\section{Conclusion}

Every thought that we think, every deed that we do, after a certain time becomes fine, goes into seed form, so to speak, lives in the fine body in the potential form and after a time it emerges again and bears its results condition the life of man. Thus he moulds his own life man is not bound by any other laws excepting those which he makes for himself. Our thoughts, our deeds, our words are the thread of the net which we throw round ourselves, for good or for 
evil. Once we set in motion a certain power, we have to take the full consequence of it. This is called law of karma. He says that soul is bound to have the law of karma, which leads him in to the chain of birth. The soul returns to the mundane life on the exhaustion of the meritorious deeds (that leads to the Svarga loka) with residual karma by the same route by which it went to (Svarga loka). The soul gains a new body suited to it from a womb. After being connected with a progenitor the soul with the residual karma enters a womb and gains a body suited to the experience of its karma.

The birth is high or low, according to the nature of residual karma

\begin{tabular}{|c|c|c|}
\hline 1 & $\begin{array}{l}\text { Yoga Vas- } \\
\text { istha }\end{array}$ & $\begin{array}{l}\text { Ignorance is the root cause of birth of mankind, Due to ajnana they born again and again in consequences of their } \\
\text { past action. Because of this they fall in materiality and forget the supreme ultimate. In the process of evaluation } \\
\text { the } 5 \text { elements prithvi, apaha, tejas, vayu and akash plays a major role. Each element represents each sense organ. } \\
\text { The soul enters in to the grain which is taken inside by human as a food and that food get converted finally into se- } \\
\text { men and this makes a cause of birth of a human. }\end{array}$ \\
\hline 2 & $\begin{array}{c}\text { Hatha } \\
\text { Rathanavali }\end{array}$ & $\begin{array}{l}\text { The span of life, wealth, education and profession are all fixed at the time of the conception itself when the union } \\
\text { take place by the healthy functioning of vata aspect of the tridosa in the womb and predictable by the science of } \\
\text { astrology. }\end{array}$ \\
\hline 3 & $\begin{array}{l}\text { Siva Sam- } \\
\quad \text { hita }\end{array}$ & $\begin{array}{l}\text { The fruits of action are twofold-heaven or hell. The good actions are verily the heaven, and sinful deeds take the } \\
\text { soul to the hell; the creation is the natural outcome of Karmas and nothing else. When the suffering (hell) of the } \\
\text { evil actions and enjoyment of good actions (heaven) are exhausted, the jiva takes rebirth. From the Annamaya } \\
\text { kosa (the physical vehicle) of the father, and in accordance with its past Karmas, the human soul is re-incarnated. }\end{array}$ \\
\hline 4 & $\begin{array}{c}\text { Patanjali } \\
\text { Yoga Sutras }\end{array}$ & $\begin{array}{l}\text { The reservoir of Karmas which are rooted in Klesas brings all kinds of experiences in the present and future lives. } \\
\text { As long as the root is there, it must ripen and result in lives of different classes, different lengths and experiences. }\end{array}$ \\
\hline 5 & $\begin{array}{l}\text { Garbha } \\
\text { Upanisad }\end{array}$ & $\begin{array}{l}\text { At the ninth lunar month, the soul is able to perceive Prakøti, Mahat, Ahañkára, } 5 \text { Tanmatrás, Manas, } 10 \text { Indriyas, } \\
5 \text { Mahabhütas a total } 25 \text {-tattvas come to the jèva. Now the soul is able to remember his previous incarnations and } \\
\text { action At the moments of birth, the soul is no longer able to remember its past, but in accordance with the law of } \\
\text { karma, which is just, the individual will be drawns from his earliest childhood to situations and condition of life, } \\
\text { which he will have deserved as a result of his thoughts and action in formers lives and which will enable him to } \\
\text { pass through the experience, necessary to his evolution. }\end{array}$ \\
\hline 6 & $\begin{array}{l}\text { Bruhad } \\
\text { aranyaka } \\
\text { Upanisad }\end{array}$ & $\begin{array}{l}\text { When soul's past work is exhausted, they reach to the air, from the air rain, and from } \\
\text { rain the earth. Reaching the earth they become food. Then they are again offered in the fire of a male, then in the } \\
\text { fire of women; then they are born and perform rites for rising to other worlds. Thus verily they rotate. }\end{array}$ \\
\hline 7 & $\begin{array}{l}\text { Chandogya } \\
\text { upanisad }\end{array}$ & $\begin{array}{l}\text { Once soul exhausted the result of action then return to Akasa, from Akasa to air, air become smoke, smoke become } \\
\text { cloud. Having become the cloud fall as rain, then they born in this world as rice, barley, herbs and trees, seasmum } \\
\text { plants and beans, who ever eats the food and seeds, they become like him only Among them, those who have } \\
\text { good residual result of action here quickly reach a good womb. But those who have bad residual results of action } \\
\text { quickly reach an evil womb, }\end{array}$ \\
\hline 8 & $\begin{array}{l}\text { Katha Upa- } \\
\text { nisad }\end{array}$ & $\begin{array}{l}\text { Some soul enters the womb for acquiring bodies and other follow the motionless, in accordance with their work } \\
\text { and in conformity With their knowledge. }\end{array}$ \\
\hline 9 & $\begin{array}{l}\text { Aitreya } \\
\text { Upanisad }\end{array}$ & $\begin{array}{l}\text { When the soul conceived and procreates its self , that is its first birth. He protect his sun just after } \\
\text { birth,thereby he protects his ownself for the sake of the continuance of these world is its second birth. } \\
\text { having of his duties fulfilled and having advance in age. Departs. As soon as he departs, he takes birth } \\
\text { again. That is his third birth. }\end{array}$ \\
\hline 10 & $\begin{array}{l}\text { Mandukya } \\
\text { Upanisad }\end{array}$ & $\begin{array}{l}\text { Soul, having enjoyed (the fruit of action) in the abode of pleasure on the heights of the heaven, enters this world } \\
\text { or an inferior one. }\end{array}$ \\
\hline 11 & $\begin{array}{c}\text { Bhagavat } \\
\text { Gita }\end{array}$ & $\begin{array}{c}\text { The endless chain of birth and death. The soul has to be born again and again because of the doctrine of karma. } \\
\text { Karma is ever associated with self-determination. there are three types of actions called desirable, agreeable, and } \\
\text { mixed -awaits the non- relinquishes (of fruits) after death but not the relinquished, So we find that a man who } \\
\text { goes to heaven as a result of his meritorious deeds may perchance have some evil impression predominant in him } \\
\text { on the exhaustion of his merits. Consequently such a person, in coming down from heaven, will have a low birth } \\
\text { in the human plane or may even descend to the subhuman level. Usually those who return from the heaven are } \\
\text { reborn on a high level of life. Therefore karma decides the birth of a soul. }\end{array}$ \\
\hline 12 & $\begin{array}{l}\text { Bhaga- } \\
\text { vat and } \\
\text { Markanday } \\
\text { Purana }\end{array}$ & $\begin{array}{c}\text { By force of karma (destiny) as directed by providence, the soul (destined to be born as a man) enters the womb of } \\
\text { a woman through the generative fluid of a man for the formation of the body. The child issues out from the womb } \\
\text { with great trouble, head downwards, breathless and deprived of memory out of agony, fallen on earth in a pool } \\
\text { of blood and urine (discharged by the mother). The new born babe tosses like a worm sprung from ordure and } \\
\text { having lost its wisdom (acquired in the womb) and reduced to a state of self-identification with the body( which is } \\
\text { just the reverse to wisdom), cries loudly. }\end{array}$ \\
\hline
\end{tabular}




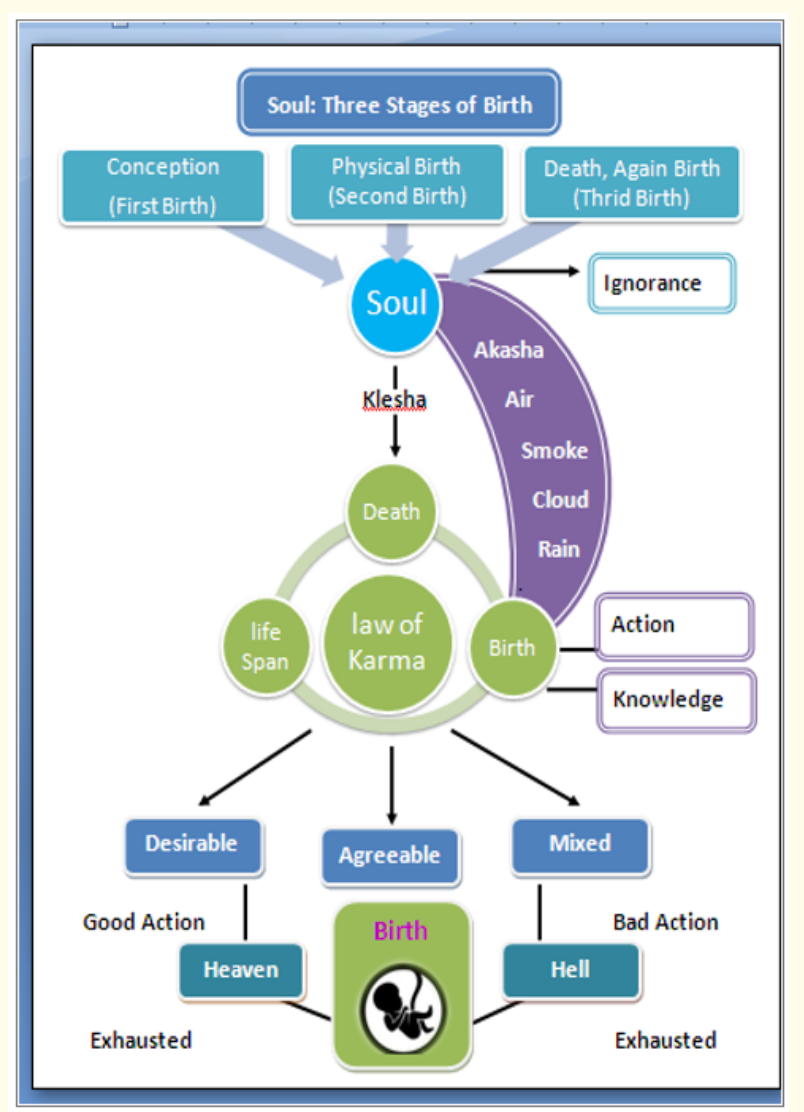

Figure

\section{Bibliography}

1. Mitra Vihari lal and Prakash Arya Ravi. "The Yoga Vasistha of Valmiki". VOLUME-IV, Nirvana- Prakarana Uttrardha, Revised Edition by Parimal publication, 27/28, Shakti nagar, Delhi 110007 (India) (2000).

2. Mitra Vihari lal and Prakash Arya Ravi. "The Yoga Vasistha of Valmiki". VOLUME-I, Vairagya Prakarana, Mumuksu Prakarana, Utratti Prakarana, Edited and Revised with Parimal publication, 27/28, Shakti Nagar, Delhi 110007 (2000).

3. Mahayogindra Srinivasa Bhatta. Hatha Ratnavali, Pub-M. Ramakrishna Reddy, Artha Muru, East Godaveri District, Andhra Pradesh (1982).

4. Rai Bahadur Srisa Chandra Vasu. Siva Samhita, Pub- Munshiram Manoharlal, New Delhi 110005 (1996).

5. IK Taimini. The Science of Yoga, The Theosophical Publishing House, Adger, Chennai (2001).

6. Brahma Kumar Jagdish Chander. Spiritual Miscellany, PubBrahma Kumaris Ishwarya Vishwa Vidyalaya, Derawal Nagar, Delhi-110009 (2000).

7. Satprakashananda Swami. The Goal and the Way, The vedantic Approach to Life's Problem by, Ramakrishna Math Road, Madras, First Edition (1981).
8. Satyam. Know Your Religion, Part- One, Published- International Vedic Centre, Jaya Nagar, and Bangalore (2000).

9. Satyam. Know Your Religion, Part- Two, Published- International Vedic Centre, Jaya Nagar, and Bangalore (2000).

10. Brian K Smith. The Laws of Manu, Pub-Penguin Books India, 43 Nehru Place, New Delhi 110019 (1991).

11. Chandrasekharendra Saraswati Swami. Hindu Dharma PubBharatiya Vidya Bhavan, Kulapati Munshi Marg, Mumbai (2000).

12. Deussan Paul. Sixty Upanishads of the Veda (Part-One) By, Motilal Banarasidas Publishers Pvt. Ltd. Delhi, Ed-First (1990).

13. Elia Sachdev. The Ideal Motherhood and Super humanity PubPrint Craft, A- 90, vishal Enclave, New Delhi (2000).

14. Chandra Kanta Suri. The Life and Time of Kunti, Pub-Books for All, Delhi (1991).

15. Janet Balaskas. Preparing for Birth with Yoga Pub-Element Books Limited, Great Britain (1994).

16. Bhagavata Mahapurana. Pub-Gita Press, Gorakhpur (1995).

17. Pandit. Kanhaiyalal Mishra. Markandeya Purana, Pub-Khemraj Shree Krishna Das Prakashana, Bombay-4 (2000).

18. Pandit Jwala Prasad Chadurvedi., et al. "The Study of Karma Sidhhanta and Astrology on the Human Longevity Based On Karma". Global Journal of Applied Sciences and Technology 2.1 (2021): 110.

19. Bapat RA., et al. "The Effect of One Month Yoga Intervention on Perceived Stress and Anxiety in Pregnant Women". Journal of Women's Health 5 (2016): 4.

Volume 3 Issue 6 June 2021

(C) All rights are reserved by Bapat Rashmi Atul., et al. 